\title{
CLINICOPATHOLOGICAL PROFILE OF SQUAMOUS CELL CARCINOMA PRESENTING IN TERTIARY CARE HOSPITAL, KARACHI.
}

1. BDS, MCPS

Senior Registrar Oral Medicine Bahria University Medical \& Dental College.

2. BDS, FCPS

Surgical Assistant in Cleft Project. Almustufa Medical Centre.

3. BDS, FCPS, Adv. Dip HPE, DCPS HCSM

Associate Professor

Liaquat College of Medicine and Dentistry.

4. BDS, MCPS

Senior Lecturer Oral Medicine Liaquat College of Medicine and Dentistry.

5. BDS, MCPS

Assistant Professor Oral Surgery Altmash Institute of Dental Medicine.

6. BDS, MSC, FDS

Principal and HOD Oral Surgery Liaquat College of Medicine and Dentistry.

Correspondence Address:

Dr. Sameera Asif

A-110, Iqbal Arcat, Garden East,

Karachi.

sameeraasif3@gmail.com

Article received on:

18/06/2019

Accepted for publication:

06/09/2019

\section{INTRODUCTION}

The profile of Squamous Cell carcinoma has changed drastically during recent decades. With the growing incidence of cases reported for Squamous cell carcinoma (SCC), it is now considered as one of the ten most common cancers in the world. ${ }^{1,2}$ In Pakistan, Oral SCC is considered as the second most common cancer diagnosed in both male and female, constituting $15 \%$ of estimated new cases compared to $3 \%$ found worldwide. ${ }^{3}$

In developing countries, the prevalence of intraoral cancer appears to be rising, especially in men due to habit of eating tobacco, betel quid and areca nut. ${ }^{4}$ These ingredients along with other factors such as alcohol consumption, low socioeconomic status, poor hygiene, poor diet,

\begin{abstract}
Sameera Asif', Summera Kanwal' ${ }^{2}$, Tahera Ayub ${ }^{3}$, Zafar Abbas ${ }^{4}$, Batool Vaziri ${ }^{5}$, Navid Rashid Qureshi ${ }^{6}$
ABSTRACT... Objectives: Oral Squamous cell carcinoma (OSCC) is the most common metastasis in different staging of squamous cell carcinoma was also recorded. Study Design: Retrospective study. Setting: Department of Oral \& Maxillofacial Surgery Liaquat College of Clict retromolar region (12 patients), maxillary alveolus ( 8 patients), tongue ( 2 patients), floor of mouth (4 patients) \& lip ( 3 patients). Right side was most common, 48 patients as compare Retal 60 patients were included in the study with the male to female ratio of 1.4:1. No of patients were male involving buccal mucosa $(51.67 \%)$ as the most frequently involved site followed by retromolar area $(20 \%)$ and tongue $(13.3 \%)$. Mean age of patients included in the with increased number of cases involving buccal mucosa as their primary site. Majority of the
\end{abstract} Key words: Malignant, Oral Squamous Cell Carcinoma, Risk Factors, Tumor Staging.

\begin{tabular}{|c|c|}
\hline Article Citation: & $\begin{array}{l}\text { Asif S, Kanwal S, Ayub T, Abbas Z, Vazir B, Qureshi NR. Clinicopathological } \\
\text { profile of squamous cell carcinoma presenting in Tertiary Care Hospital, } \\
\text { Karachi. Professional Med J 2020; } 27(5): 939-943 \text {. } \\
\text { DOI: } 10.29309 / T P M J / 2020.27 .05 .3831\end{array}$ \\
\hline
\end{tabular}

and viral infections, chronic irritation from ill-fitting dentures, rough, or fractured teeth. ${ }^{5,6}$ The most common sites of occurrence of oral squamous cell carcinoma (OSCC) are buccal mucosa and tongue. ${ }^{7}$ Altogether, they serve as strong risk factors for development of Oral SCC and other potentially malignant disorders. ${ }^{8}$

Recently oncogenic human papillomavirus (HPV) is suspected to be the pre-cursor of increased number of cases of Oro-pharyngeal SCC reported worldwide. ${ }^{9}$ In UK, $51.8 \%$ of the cases of OSCC diagnosed between 2002 and 2011 were HPVpositive. Thorough examination and evaluation of possible contenders is therefore necessary to rule out the cause of malignancy. ${ }^{10-12}$

This retrospective institutional study was 
conducted with the aim of describing the demographic and Clinicopathological profile of cases of OSCC reported at the Oral \& Maxillofacial Surgery Department in Liaquat College of Medicine \& Dentistry, Karachi, during a 4-year period, to highlight the magnitude of problem and find the trends of the occurrence of OSCC in Pakistan.

\section{MATERIAL \& METHODS}

The study carried out in Tertiary care hospital and included 60 patients from the year June 2013- July 2016. Patients presenting with recurrence or metastasis were not included in the study. It included 35 males and 25 females which presented with different sites and stage of squamous cell carcinoma. Clinically patients were staged as stage I, stage II, stage III and stage IV and comprised of 3, 8, 30 \& 19 patients respectively. Patients included in the study were aged between 40-60 years. Analysis was done using SPSS version 23. Patients presenting with recurrence or metastasis were excluded from the study.

All the patients included in the study underwent modified radical neck dissection along with excision of primary tumor with $1 \mathrm{~cm}$ safe margin. The excised tissue was sent for histopathological analysis and results obtained.

\section{RESULTS}

The clinicopathological profile of all the subjects under study was analyzed in detail. Total numbers of patients included in the study were 60. The parameters assessed in the study were site and staging of the disease. Age and gender distribution was also considered but no significant association was seen between age group and gender.

Among the patients 35 were male and 25 patients were female. Thus the sex ratio was 1.4:1. The mean age for male sample was $51.14 \pm 5.61$ and for female sample it was $50.6 \pm 5.53$ (Table-l) p-value obtained using Pearson chi square test, showed that, there was no significant association between age group and gender.

\begin{tabular}{|c|c|c|c|c|c|}
\hline Age & $\begin{array}{c}\text { Male } \\
(\mathbf{n})\end{array}$ & $\begin{array}{c}\text { Male } \\
\%\end{array}$ & $\begin{array}{c}\text { Female } \\
(\mathbf{n})\end{array}$ & $\begin{array}{c}\text { Female } \\
\%\end{array}$ & $\begin{array}{c}\text { P- } \\
\text { Value }\end{array}$ \\
\hline $40-45$ & 12 & 34.29 & 10 & 40 & \\
\hline $45-50$ & 10 & 28.57 & 6 & 24 & \multirow{2}{*}{0.933} \\
\hline $50-55$ & 06 & 17.14 & 5 & 20 & \\
\hline $55-60$ & 07 & 20 & 4 & 16 & \\
\cline { 1 - 4 } & Table-l. Age and gender distribution \\
\hline
\end{tabular}

Out of 60 patients, buccal mucosa was seen as the most common site for occurrence of Oral squamous cell carcinoma seen in 31 patients (51.67), followed by Retromolar region 12(20\%), Floor of the mouth 04(6.67\%), tongue 8 (13.34\%), lip $3(5 \%)$ and maxillary alveolus 2(3.34\%) respectively. (Table-II)

Regarding staging of the tumor, majority of the patients reported had stage 3 seen in 30(50\%) patients followed by Stage 4 in 19(31.67\%), stage 2 in $8(13.33 \%)$ and stage 1 in $3(5 \%)$ patients respectively. (Table-III)

\begin{tabular}{|l|c|c|}
\hline \multicolumn{1}{|c|}{ Site } & $\begin{array}{c}\text { Number of Patients } \\
(\mathbf{n = 6 0 )}\end{array}$ & Percentage \\
\hline Buccal Mucosa & 31 & 51.67 \\
\hline Retromolar region & 12 & 20 \\
\hline Floor of Mouth & 04 & 6.67 \\
\hline Lip & 03 & 5 \\
\hline Tongue & 08 & 13.34 \\
\hline Maxillary Alveolus & 02 & 3.34 \\
\hline \multicolumn{1}{|c|}{ Table-II. Site involvement in patients } & with SCC \\
\hline Clinical Stage & $\begin{array}{r}\text { Number of Patients } \\
\text { (n=60) }\end{array}$ & $\%$ \\
\hline Stage I & 3 & 5 \\
\hline Stage II & 8 & 13.33 \\
\hline Stage III & 30 & 31.67 \\
\hline Stage IV & 19 & \\
\hline \multicolumn{2}{|c|}{ Table-III. Clinical Staging of the disease } \\
\hline
\end{tabular}

\section{DISCUSSION}

OSCC is widely recognized as the most common malignant tumor occurring in the oral cavity. More than $90 \%$ of the cancers reported in oral cavity are squamous cell carcinomas with relatively high mortality and survival rate of $50 \%$. $^{2,13}$

The study was carried out to highlight the 
trends associated with OSCC and to assess clinicopathological profile of patients which may help in formulating therapeutic treatment plan. A total of 60 patients were included in the study after histological confirmation of the disease. The mean age range was $50.87 \pm 5.53$. The age ranges of patients were 40-60 years indicating the occurrence of disease in $5^{\text {th }}$ and $6^{\text {th }}$ decades of life. These findings were consistent with the studies conducted in Karachi ${ }^{14}$ and Lahore ${ }^{3}$ demonstrating the occurrence of disease in $5^{\text {th }}$ decade of life. Rahmanet al ${ }^{15}$ reported $50.46 \pm$ 3.78 years mean age which is consistent with our study.

The male to female ratio in the study was $1.4: 1$ showing male predilection. The high chances of occurrence of disease in male population are confirmed by various local ${ }^{16}$ and international researches ${ }^{17,18}$ conducted on the subject. This gender distribution is attributed to the increase consumption of betel nut, tobacco and smoking as seen higher in male population compared to female. In this study also majority of patient reported were males. However, the current study did not revealed any significant association between age group and gender.

Regarding the site of OSCC, buccal mucosa was identified as the most frequently involved site followed by retromolar region and tongue respectively. This finding was similar to the study conducted by Jayasooriyaetal which states that $43 \%$ of patient reported with OSCC involving buccal mucosa. ${ }^{19}$ Bhurgri $^{20}$ in her report from South Karachi demonstrated that among oral malignancy, the buccal mucosa was most frequently involved (55.9\%) as concurrently seen in our study.

This increase in the incidence of OSCC of buccal mucosa preferably in our part of the world is due to habit of keeping betel nut and gutka in the buccal pouch for longer duration of time which significantly produce a sense of well-being and increased capacity to work by stimulation of parasympathetic nervous system ${ }^{21}$ and increases the accumulation of carcinogenic substance into the involved area., ${ }^{3,22}$ In contrary to this, international literature shows tongue as the most commonly involved site followed by floor of the mouth attributed to increase exposure of carcinogenic substances through smoking. ${ }^{23,24}$ This finding is also consistent with the study conducted by Syamet al. ${ }^{25}$

Ebrahimiet $\mathrm{al}^{26}$ have reported that $\mathrm{T}$ stage and $\mathrm{N}$ stage were important factors affecting regional recurrence in OSCC. In our study, majority of the patients presented with stage 3 and 4 which is in agreement with the findings of studies conducted by Daniel atal ${ }^{27}$ which states that $66 \%$ of the oral carcinomas evaluated was diagnosed at advanced stages. ${ }^{28,29}$ About two-thirds of oral SCC are already of substantial size, and will have clinically detectable metastases to cervical lymphnodes at the time of diagnosis. ${ }^{29,30}$ Early diagnosis of the disease is therefore essential for improvement in the survival rate of the cases diagnosed with OSCC.

The limitations of the current study are small sample size and involvement of one tertiary care facility for evaluating the clinicopathological parameters. Study with involvement of other centres should be conducted to rule out the generalized findings of the disease. Moreover, determination of histological grading and survival rate are important predictors which will be included in future studies.

\section{CONCLUSION}

Most of the cases of OSCC reported in the tertiary care hospital are seen in $5^{\text {th }}$ and $6^{\text {th }}$ decades of life with buccal mucosa as the most common site involved owing to the increase consumption of carcinogenic substances. Majority of the cases are diagnosed in advanced stages which affect the prognosis of the tumour and substantially reduces the survival rate. It is therefore essential that frequent oral examination and awareness campaigns should be performed for early detection of the lesion which may impart significant reduction in mortality rate.

\section{CONFLICT OF INTEREST}

Authors declare NO conflict of interests

Copyright $@ 06$ Sep, 2019. 


\section{REFERENCES}

1. Tandon A, Bordoloi B, Jaiswal R, Srivastava A, Singh RB, Shafique U. Demographic and clinicopathological profile of oral squamous cell carcinoma patients of North India: A retrospective institutional study. SRM J Res Dent Sci 2018; 9:114-8.

2. Warnakulasuriya S. Global epidemiology of oral and oropharyngeal cancer. Oral Oncol 2009; 45:309-16.

3. Sahaf R, Naseem N, Rehman A, Anjum R, Nagi AH. A study of 89 cases of oral squamous cell carcinoma presenting at Teaching Hospitals of Lahore, Pakistan. J Pak Dent Assoc 2017; 26(1): 26-31.

4. Scully C. Oral cancer aetiopathogenesis; Past, present and future aspects. Med Oral Patol Oral Cir Bucal. 2011 May 1; 16(3):306-11.

5. Scully C. Cancers of the Oral Mucosa. Medscape; 2016. Available from: http://www.emedicine.medscape. com/article/1075729overview\#a6. [Last accessed on 2017 Jun 29].

6. Aruna DS, Prasad KV, Shavi GR, Ariga J, Rajesh G, Krishna M, et al. Retrospective study on risk habits among oral cancer patients in Karnataka cancer therapy and research institute, Hubli, India. Asian Pac J Cancer Prev 2011; 12:1561-6.

7. Krishna Rao SV, Mejia G, Roberts-Thomson K, Logan R. Epidemiology of oral cancer in Asia in the past decade - An update (2000-2012). Asian Pac J Cancer Prev 2013; 14:5567-77.

8. Khan Z, Tonnies J, Muller S. Smokeless tobacco and oral cancer in South Asia: A systematic review with meta-analysis. J. Cancer Epidemiol. 2014; 2014:394696. doi: 10.1155/2014/394696.

9. Schache AG, Powel ING, Cuschieri KS, et al. HPV related oropharynx cancer in the United Kingdom: An evolution in the understanding of disease etiology. Cancer Res 2016; 76:6598-606.

10. Martinez RC, Sathasivam HP, et al. Clinicopathological features of squamous cell carcinoma of the oral cavity and oropharynx in young patients. $\mathrm{Br} \mathrm{J}$ Oral Maxillofac Surg. 2018 May; 56(4):332-337.

11. Applebaum KM, Furniss CS, Zeka A, Posner MR, Smith $\mathrm{JF}$, Bryan J, et al. Lack of association of alcohol and tobacco with HPV16-associated head and neck cancer. J Natl Cancer Inst. 2007; 99:1801-10.
12. Patel AS, Karagas MR, Perry AE, Nelson HH. Exposure profiles and human papillomavirus infection in skin cancer: An analysis of $\mathbf{2 5}$ genus $\beta$-types in a population based study. J Invest Dermatol. 2008; 128(12):2888-93.

13. Jin X, Liu D, Zhao X, Zhou Y, Jiang L, Li J, et al. Analysis of clinicopathological characteristics associated with the outcome of oral squamous cell carcinoma and the establishment of tissue microarrays. Oncol Lett 2016; 12:3175-82.

14. Akram S, Mirza T, Mirza MA, Qureshi M. Emerging patterns in clinico-pathological spectrum of oral cancers. Pak J Med Sci. 2013; 29:783-787.

15. Rahman SS, Sarker MK, Khan MHA, Biswas SS, Saha MM. Clinical profile of oral squamous cell carcinoma patients attending a tertiary care hospital. Bang Med J Khulna.2014; 47: 3-6.

16. Khaleel ME, Raza A, Ehsan A, Masood R, Javed M. Clinicopathological spectrum of oral squamous cell carcinoma at a public sector health facility. Biomedica. 2015; 31: 21-6.

17. Chiang CT, Hwang YH, Su CC, Tsai KY, Lian I, Yuan TH. Elucidating the underlying causes of oral cancer through spatial clustering in high-risk areas of Taiwan with a distinct gender ratio of incidence. Geospat Health. 2010; 4:230-242.

18. Tahas IA, Younis WH. Clinicopathological analysis of oral squamous cell carcinoma in Iraq during period (2001-2013). J BaghColl Dentistry. 2015; 27:58-65.

19. Primali Rukmal Jayasooriya, Thushara Nilmini Pitakotuwage, Balapuwaduge Ranjit Rigorbert Nihal Mendis and Tommaso Lombardi. Descriptive study of 896 Oral squamous cell carcinomas from the only University based Oral Pathology Diagnostic Service in Sri Lanka. BMC Oral Health, 2016; 16(1): 1.

20. Bhurgri Y. Cancer of the oral cavity - trends in Karachi South (1995-2002). Asian Pac J Cancer Prev. 2005; 6:22-6.

21. Madani $A H$, Dikshit $M$, Bhaduri $D$, Jahromi AS, Aghamolaei T. Relationship between selected sociodemographic factors and cancer of oral cavity - A case control study. Cancer Inform 2010; 9:163-8.

22. Ayaz B, SaleemK, Azim W, Shaikh A. A clinicopathological study of oral cancers. Biomedica. 2011; 27(1):29-32.

23. Tanaka T, Ishigamori R. Understanding carcinogesesis for fighting oral cancer. J Oncol. 2011; 1-10. 
24. Schmidt BL, Dierks EJ, Homer L, Potter B. Tobacco Smoking History and Presentation of Oral Squamous Cell Carcinoma. J Oral Maxillofac Surg. 2004; 62:10551058.

25. Syamsundar B, Nageswara RR, Faheem MK. Epidemiological and clinico pathological study of oral cancers in a Tertiary care hospital. Int $\mathrm{J}$ Biol Med Res. 2012; 3:2376-2380.

26. Ebrahimi A, Clark JR, Zhang WJ, et al. Lymph node ratio as an independent prognostic factor in oral squamous cell carcinoma. Head Neck. 2011; 33:12451251.

27. D. Brandizzi, M. Gandolfo, M. L. Velazco, R. L. Cabrini and H. E. Lanfranchi, "Clinical Features and Evolution of oral cancer: A study of 274 cases in Buenos Aires, Argentina," Medicina Oral, Patologia Oral, CirugiaBucal. 2008; 13(9): 544-548.
28. Navarro Vila C, Cuesta Gil M, Lopez de Ayala Gutierrez J. Advanced stage (T3-4) squamous cell carcinoma of the oral cavity: Therapeutic results of 375 cases after 5 years of follow-up. Med Oral. 1998 Jan; 3(1):717.

29. Feller L, Lemmer J. Oral squamous cell carcinoma: Epidemiology, clinical presentation and treatment. $J$ Cancer Ther 2012; 3:263-8.

30. Woolgar JA, Rogers SN, Lowe D, Brown JS, Vaughan ED. Cervical lymph node metastasis in oral cancer: The importance of even microscopic extracapsular spread. Oral Oncol. 2003 Feb; 39(2):130-7.

\begin{tabular}{|c|c|c|c|}
\hline \multicolumn{4}{|c|}{ AUTHORSHIP AND CONTRIBUTION DECLARATION } \\
\hline Sr. \# & Author(s) Full Name & Contribution to the paper & Author(s) Signature \\
\hline 1 & Sameera Asif & $\begin{array}{l}\text { Manuscript writing, Data } \\
\text { acquisition and analysis. }\end{array}$ & \\
\hline 2 & Summera Kanwal & Data collection and analysis. & \\
\hline 3 & Tahera Ayub & Critical review of the findings. & \\
\hline 4 & Zafar Abbas & Data collection. & \\
\hline 5 & Batool Vazir & Critical review, Final approval & \\
\hline 6 & Navid Rashid Qureshi & Data collection. & Butors. \\
\hline
\end{tabular}

